\title{
An Overview of Carcinogenic Heavy Metal: Molecular Toxicity Mechanism and Prevention
}

\author{
Hyun Soo Kim*, Yeo Jin Kim*, Young Rok Seo \\ Institute of Environmental Medicine for Green Chemistry, Department of Life Science, Dongguk University Biomedical Campus, Goyang, Korea
}

\begin{abstract}
Almost all heavy metals are serious toxicants as carcinogens. However, due to their chemical and physiological properties, heavy metals are useful in industrial areas including alloy, smelting and production of commercial products. Such applications increase the opportunity for heavy metal exposure. Waste from industrial processes is also a major source of environmental contamination and accumulation in the human body. Arsenic, cadmium, chromium, and nickel are classified as group 1 carcinogens by the International Agency for Research on Cancer, and are utilized commercially. In this review, we used molecular pathway analysis to understand the toxicity and carcinogenic mechanisms of these metals. Our analyzed data showed that above-mentioned metallic substances induce oxidative stress, DNA damage, and cell death processes, resulting in increase the risk of cancer and cancer-related diseases. Thus, we might think phytochelatin molecules and antioxidative phytochemical substances are helpful for prevention of heavy metal-induced cancer.
\end{abstract}

(J Cancer Prev 2015;20:232-240)

Key Words: Carcinogenic heavy metals, Molecular mechanism, Pathway analysis, Cancer prevention

\section{INTRODUCTION}

Most heavy metals are one cancer-inducing agents. ${ }^{1}$ Although several heavy metals, including copper $(\mathrm{Cu})$ and zinc $(\mathrm{Zn})$, serve as enzymes that are essential for intracellular processes and have DNA-binding domains, almost all heavy metals induce various cancers and diseases. ${ }^{2-4}$ Oxidative stress caused by reactive oxygen species (ROS) is a well-known mechanism of heavy metal-induced damages. ${ }^{1.5}$ Despite such serious toxicity, heavy metals are utilized in various industrial products; they are found in batteries, paints, and vehicle emissions. Furthermore, heavy metals are used in pigments that are then used in consumer products like children's jewelry and toys. ${ }^{6}$ Electronic waste from heavy metal-containing batteries is an important source of heavy metal contamination in the environment through erosion by rain and groundwater flow to soil, rivers and the sea. Dissolved forms of toxic heavy metals can be magnified via circulation in the bio-system, including the food chain, and finally end up in very high concentrations in humans. ${ }^{1,5,7}$

Arsenic (As), cadmium (Cd), chromium ( $\mathrm{Cr}$ ), and nickel (Ni) are category 1 heavy metals according to the International agency for Research on Cancer. ${ }^{8}$ Various reports have found that exposure to these compounds leads to disruptions in tumor suppressor gene expression, damage repair processes, and enzymatic activities concerned in metabolism via oxidative damage. ${ }^{5.9}$ Some studies have indicated that the risk of heavy metal exposure is interrelated with the contamination source. ${ }^{10,11}$ For example, recent studies found an increased risk of occupational disease and cancer in workers in heavy metal-using industrial areas. ${ }^{12,13}$

Nowadays, massive floods of biological data are available because of increased attention to health and biology, so the importance of data-mining techniques is a main issue. The Pathway

Received December 9, 2015, Revised December 12, 2015, Accepted December 14, 2015

Correspondence to: Young Rok Seo

Institute of Environmental Medicine for Green Chemistry, Department of Life Science, Dongguk University Biomedical Campus, 32 Dongguk-ro, Ilsandong-gu, Goyang 10326, Korea

Tel: +82-31-961-5172, E-mail: seoyr@dongguk.edu

*These authors contributed equally to this work as co-first authors.

Copyright (C) 2015 Korean Society of Cancer Prevention

(c) This is an Open Access article distributed under the terms of the Creative Commons Attribution Non-Commercial License (http://creativecommons.org/licenses/by-nc/4.0) which permits unrestricted non-commercial use, distribution, and reproduction in any medium, provided the original work is properly cited. 
Studio database can help to understand the gene/chemicalspecific complex pathways as it provides pathway drawings using data from multitude of sources. ${ }^{14}$ Using pathway analysis is one way to provide a comprehensive view of heavy metal-induced carcinogenesis, disease, and marker proteins. In addition, direct connectivity between marker proteins and cellular processes contributes to the prediction of carcinogenesis-specific protein markers.

Various intracellular chelation processes and antioxidants are involved in the prevention and detoxification of heavy metalinduced damage. Chelating agents in plants called phytochelatins $(\mathrm{PCs})$ combine with metal ions and provide resistance to metal poisoning. ${ }^{15,16}$ Antioxidant molecules interact with free radicals and protect from oxidative damage. ${ }^{17}$ Consumption of phytochemicals from antioxidant substances from plants can assist in the antioxidant-related detoxification process. ${ }^{18}$

In this review, we will explain the toxicity and carcinogenicity of heavy metals like As, $\mathrm{Cd}, \mathrm{Cr}$, and Ni by providing a comprehensive understanding their toxicological mechanisms with using molecular pathway analysis. In addition, we present the cancer prevention properties of PCs and antioxidant such as phytochemicals.

\section{ARSENIC (As)}

\section{Contamination source}

As is a metalloid that exists in inorganic and organic compound forms. Inorganic As is more harmful than the organic form. Pentavalent inorganic compounds of As solubilize in water to weak acid forms and produce salts called arsenate..$^{19}$ Arsenate induces ground water contamination that affects many people. ${ }^{20,21}$ Recently, As has been used for the isotope labeling in cancer research, instead of radioactive elements, and is mainly used for industrial purposes, including the manufacture of car batteries and alloyed semiconductor materials, and pigments. ${ }^{19,22.23}$ Mining and ore smelting for industrial purposes are related to As poising in humans, but the major source of As exposure is from natural sources, such as contaminated water. ${ }^{20,21}$ Arsenates in the soil can dissolve easily in groundwater and flow to rivers and the sea. As accumulates in aquatic organisms, where it is converted to its organic compound form. In addition, As-contaminated groundwater may be taken up by crop plants including rice, and therefore highly accumulate in individuals who eat rice as a staple food. ${ }^{24,25}$ Thus, consumption of crops grown in As-contaminated groundwater contributes to the As accumulation in humans and increases the risk of poisoning.

\section{Toxicity and carcinogenic mechanism}

The major mechanism of As-related damage is oxidative stress. ${ }^{26,27}$ It can cause numerous diseases which disrupt cellular signaling pathways. In an in vitro cell line study, arsenical compounds led to genotoxicity in mice leucocytes and human. ${ }^{2830}$ The methylated form of arsenic inhibits DNA repair processes and also produces ROS in spleen and liver as metabolic products. ${ }^{31,32}$ Accumulation of free radicals from ROS results in cell death via abnormal gene expression and lesions of cellular components including DNA, lipids, and proteins. ${ }^{33}$ Chemical residues of As can bind to DNA-binding proteins and increase the risk of carcinogenesis via disruption of DNA repair processes. For example, As binds methyl-transferase and induces suppression of tumor suppressor gene-coded DNA with methyl-transferase. ${ }^{34}$ Recent studies uncovered the reasons for tissue toxicity of As accumulation. Methylated metabolites of As cause urinary bladder cancer by ROS generation in As-exposed rats. ${ }^{35.36}$ Hepatic function is also disrupted by As toxicity because of cross-linking with enzymes and oxidative DNA damage in rats. ${ }^{37}$

In order to understand the carcinogenic mechanism of As, we conducted the pathway analysis with Pathway Studio ver. 11.1.0.6 (Elsevier, Amsterdam, Netherlands) (Fig. 1). Figure 1 showed that As poisoning was mainly associated with apoptosis, cell damage, oxidative stress, cell cycle, and DNA damage response. We found genomic interactions among tumor protein 53 (TP53), interferon gamma, catalase, etc. Those genes are also related to As. We also discovered that cancers of skin, liver, prostate, kuffer cell were associated with As poisoning. This result may provide aid to comprehensive understanding of As-related mechanisms.

\section{CADMIUM (Cd)}

\section{Contamination source}

$\mathrm{Cd}$ is rare in the natural in environment. It generally comes from environmental pollution from industrial and agricultural waste. ${ }^{38}$ Although it is fatally toxic, $\mathrm{Cd}$ is used in batteries and electroplating. ${ }^{39,40}$ In addition, it is a component of paint for plastic products and chalk pastels, acrylic colors, and watercolor pigments. ${ }^{41}$ Recently, in laboratory experiments, $\mathrm{Cd}$ with helium was shown to be a common component of blue-ultraviolet light in fluorescence microscopes. ${ }^{42}$ In agriculture, some fertilizers which contain $\mathrm{Cd}$ cause an increase of $\mathrm{Cd}$ concentration in the soil. Farmland near industrial areas becomes contaminated. ${ }^{38,43}$ The major source of human $\mathrm{Cd}$ exposure is food intake. Itai-itai disease, for instance, is caused by $\mathrm{Cd}$ in crop plants that were 


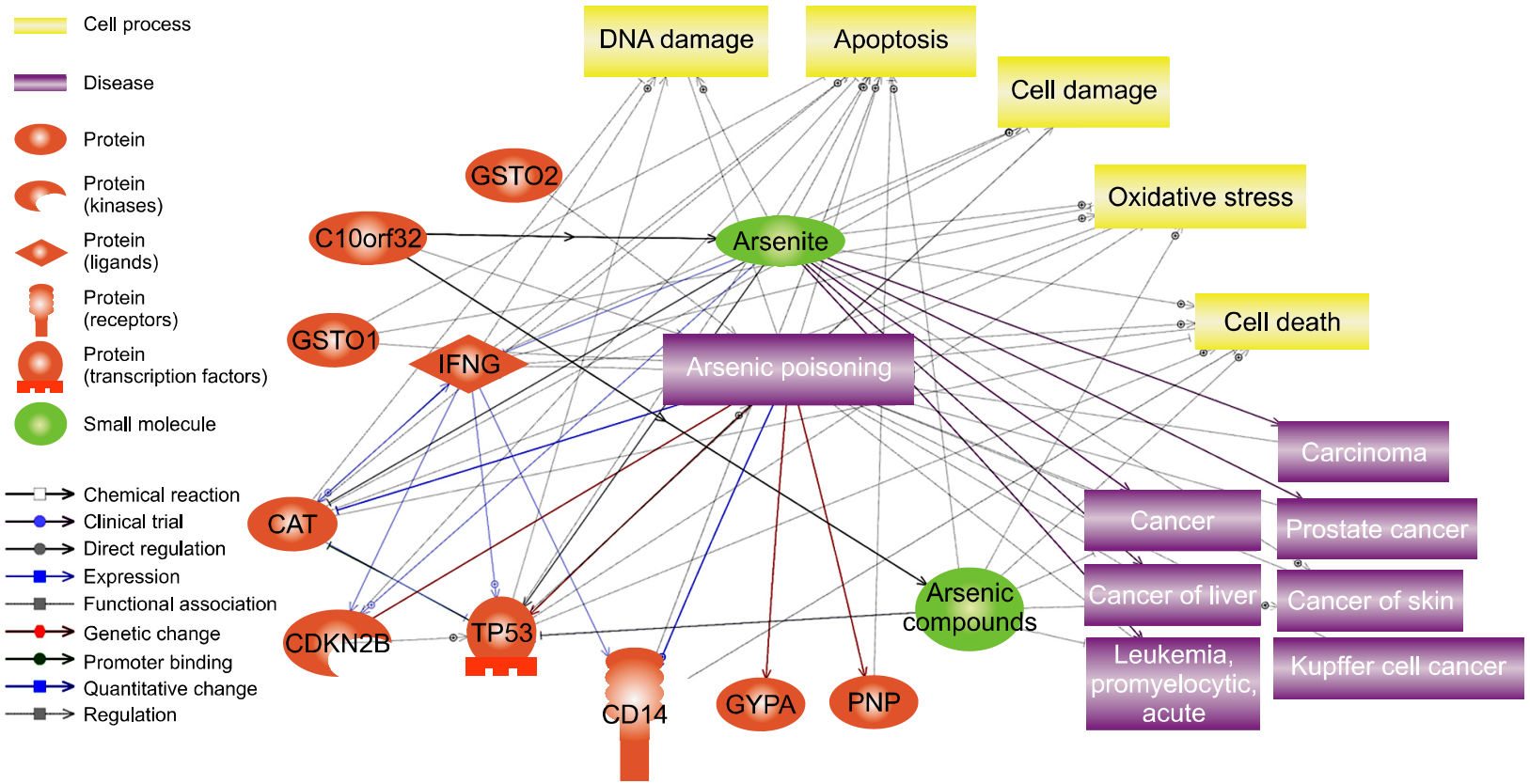

Figure 1. Pathway analysis of arsenic toxicity. The analyzed data showed the potentials of genomic interaction, cellular processes, and diseases induced by exposure of arsenic. Ten proteins, 5 cellular processes, 8 diseases and 2 small molecules appeared in figure. GSTO, glutathione-S-transferase omega; C10orf32, chromosome 10 open reading frame 32; IFNG, interferon gamma; CAT, catalase; CDKN2B, cyclin-dependent kinase 4 inhibitor 2B; TP53, tumor protein 53; CD14, monocyte differentiation antigen CD14; GYPA, glycophorin-A; PNP, purine nucleoside phosphorylase.

grown with Cd-contaminated water. ${ }^{44}$ Plants in non-industrial areas contain less $\mathrm{Cd}$, but animals that live in such areas contains high levels of Cd because of biomagnification through the food chain via $\mathrm{Cd}$ dissolved in groundwater and rivers exposed to Cd-contaminated soil. Furthermore, Cd flowed from rivers to the sea and accumulated in marine organisms. ${ }^{45,46}$ Hence, humans, the apex predators, are exposed to the risk of $\mathrm{Cd}$ poisoning.

\section{Toxicity and carcinogenic mechanism}

The most well-documented reason for Cd-related toxicity is oxidative stress. Research on chronic exposure to $\mathrm{Cd}$ in a rat model showed that liver and kidney toxicity are induced via inhibition of components of the cellular antioxidant system. ${ }^{47-49}$ Oxidative stress following $\mathrm{Cd}$ exposure accelerates of transcriptional activity of the metallothionein (MT) coding gene. MT is a ubiquitous protein in most bodily organs. It can form a complex with metal elements such as $\mathrm{Cd} .{ }^{50}$ When chronic $\mathrm{Cd}$ exposure occurs, a complex form of $\mathrm{Cd}$ and MT called Cd-MT is found, especially in the kidney. It accumulates in tubules via a reuptake process and causes conformational change of renal tubular cell as well as degradation of glomerular cell function. These functional problems disrupt calcium metabolism and augment the calcium load in the kidney, thereby resulting in an increase of kidney stones and cancer. ${ }^{51.52}$ Moreover, disruption of calcium metabolism causes bone damage. Increasing the $\mathrm{Cd}$ concentration in the kidney means high excretion of calcium in the urine and is significantly related to calcium concentration decrease in bones. It results in bone pain, osteomalacia, osteoporosis, and itai-itai disease. ${ }^{53-55} \mathrm{Cd}$ is also an as endocrine disrupter, especially of reproductive hormones. ${ }^{56.57} \mathrm{Cd}$ mimics Zn's divalent chemical state, so it can interfere with the DNA Zn binding site. It disrupts the ovarian steroidogenic pathway, production of progesterone and testosterone, and mimics endogenous estrogen, thus increasing the risk of ovarian cancer and breast cancer. ${ }^{56.58 .59}$

In order to understand the carcinogenic mechanism of $\mathrm{Cd}$, we did pathway analysis with Pathway Studio (ver. 11.1.0.6) (Fig. 2). Figure 2 showed that $\mathrm{Cd}$ poisoning is mainly associated with apoptosis, oxidative stress, and DNA damage response. In addition, genomic interactions between $B$ cell lymphoma 2 protein (BCL2)-associated $X$ protein $(\mathrm{BAX})$, mitogen-activated protein kinase 1, huntingtin, etc. were presented. Those genes are also connected with $\mathrm{Cd}$. Correlation of PC, MT, and Cd ion were shown. We also discovered that numerous diseases in bone and kidney were associated with $\mathrm{Cd}$ poisoning. This figure may provide help to comprehensive understanding of Cd-related toxicity mechanisms.

\section{CHROMIUM (Cr)}

\section{Contamination Source}

Cr is abundant in the earth's crust, and its toxicity depends on 


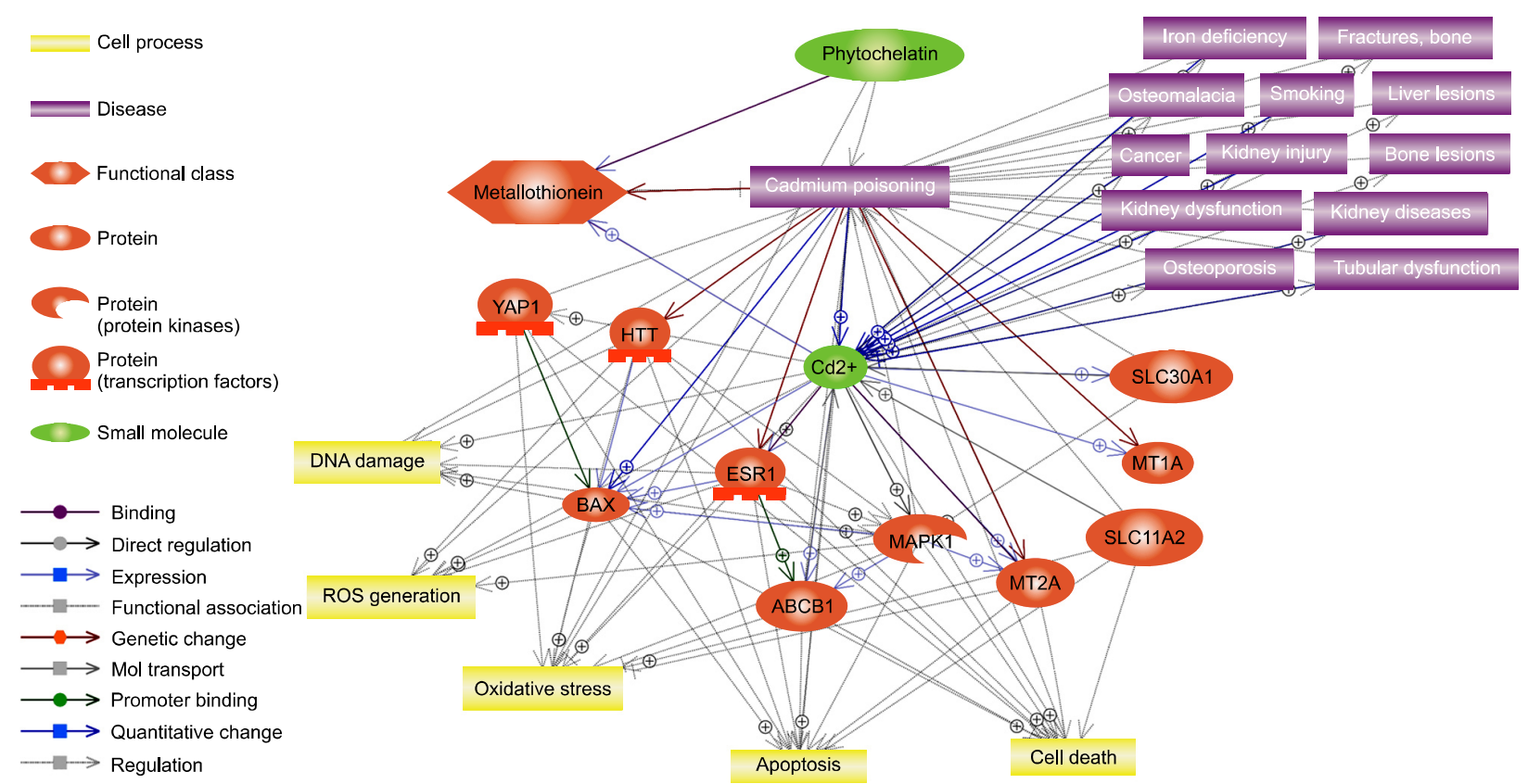

Figure 2. Pathway analysis of cadmium toxicity. The analyzed data showed the potentials of genomic interaction, cellular processes, and diseases induced by exposure of cadmium. Ten proteins, 5 cellular processes, 13 diseases, 2 small molecules and 1 functional class appeared in figure. YAP1, yes-associated protein 1; HTT, huntingtin; BAX, B cell lymphoma 2 protein-associated X protein; ROS, reactive oxygen species: ESR1, estrogen receptor 1; MAPK1, mitogen-activated protein kinase 1; ABCB1, aTP-binding cassette sub-family B member 1; MT2A, metallothionein 2A; SLC11A2, solute carrier family 11, member 2; MT1A, metallothionein 1A; SLC30A1, solute carrier family 30, member 1.

its chemical state. ${ }^{60}$ It exists in divalent to hexavalent compounds, but only the trivalent and hexavalent compounds have significant biological toxicity. ${ }^{61-63} \mathrm{Cr}$ compounds are usually found in industrial purposes such as chromite ore mining, pigment production, tanning of leather, formation of wood preservatives, and anticorrosive agents in cooking goods. Paint is a significant source of hexavalent $\mathrm{Cr}$ but is still used for industrial applications. ${ }^{64,65}$ The salt form of trivalent and hexavalent $\mathrm{Cr}$ compounds, called chromate, are produced through mining, smelting, roasting and extraction. Chromates generate the toxic dust during manufactural processes. Several studies had investigated that toxicity about $\mathrm{Cr}$ dust in chromate production workers. ${ }^{65.66}$ Furthermore, industrial wastes from $\mathrm{Cr}$ manufacturing are known as significant source of the soil and water pollution. ${ }^{67,68}$

\section{Toxicity and carcinogenic mechanism}

The carcinogenicity of $\mathrm{Cr}$ dust has been studied since the 1980s. In a case study, lung cancer occurred more often in workers in the chromate-producing industry. ${ }^{65-67.69}$ Trivalent compounds included in $\mathrm{Cr}$ dust are water-insoluble, but can enter cells in ionized form via a specific membrane transport system. High concentrations of trivalent $\mathrm{Cr}$ can lead to cellular damage. ${ }^{62}$ Hexavalent $\mathrm{Cr}$ is also a strong toxicant as it produces reactive hydroxyl radicals. In blood vessels, for example, $\mathrm{Cr}$ compounds are reduced from hexavalent to trivalent and reactive hydroxyl radicals are produced during the process. Thus, high levels of hexavalent $\mathrm{Cr}$ in the bloodstream cause blood cell damage by oxidation and functional degradation of the liver and kidney. ${ }^{70-72}$ If hexavalent $\mathrm{Cr}$ compounds are reduced to the pentavalent form, they can bind DNA and interrupt cellular processes. ${ }^{62,71,73}$ Furthermore, $\mathrm{Cr}$ in soil and water involve skin damage by absorption. ${ }^{74}$

In order to understand the carcinogenic mechanisms of $\mathrm{Cr}$, we investigated molecular pathway analysis using Pathway Studio (ver. 11.1.0.6) (Fig. 3). Figure 3 showed that $\mathrm{Cr}$ and $\mathrm{Cr}$ compounds were mainly induce apoptosis, oxidative stress and DNA damage. We found $\mathrm{Cr}$-related genomic interactions among nuclear factor (erythroid-derived 2)-like 2 (NFE2L2, Nrf2), TP53, BAX etc. Association between MT, which was mentioned with Cd toxicity, and $\mathrm{Cr}$ was also investigated. In addition, we also discovered that considerable diseases including lung cancer, skin allergy with dermatitis, and kidney diseases were induced by $\mathrm{Cr}$ and $\mathrm{Cr}$ compounds. These results may aid to comprehensive understanding of $\mathrm{Cr}$-related toxicity mechanisms. 


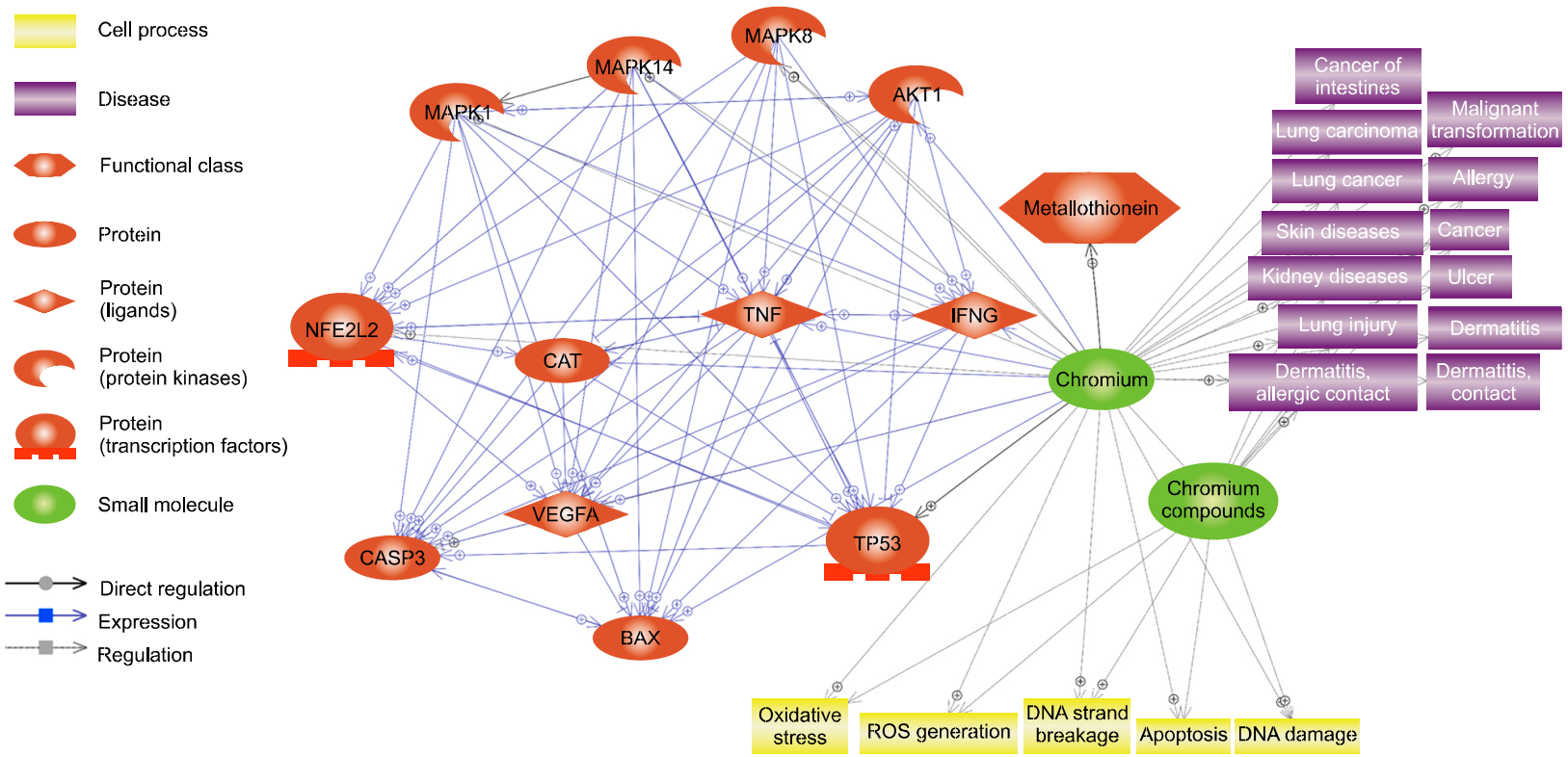

Figure 3. Pathway analysis of chromium toxicity. The analyzed data showed the potentials of genomic interaction, cellular processes, and diseases induced by exposure of chromium. 12 proteins, 5 cellular processes, 13 diseases, 2 small molecules and 1 functional class appeared in figure. MAPK, mitogen-activated protein kinase; AKT1, V-akt murine thymoma viral oncogene homolog 1; NFE2L2, nuclear factor, erythroid 2-like 2; CAT, catalase; IFNG, interferon gamma; CASP3, caspase 3, apoptosis-related cysteine peptidase; VEGFA, vascular endothelial growth factor A; TP53, tumor protein 53; BAX, B cell lymphoma 2 protein-associated $\mathrm{X}$ protein; ROS, reactive oxygen species.

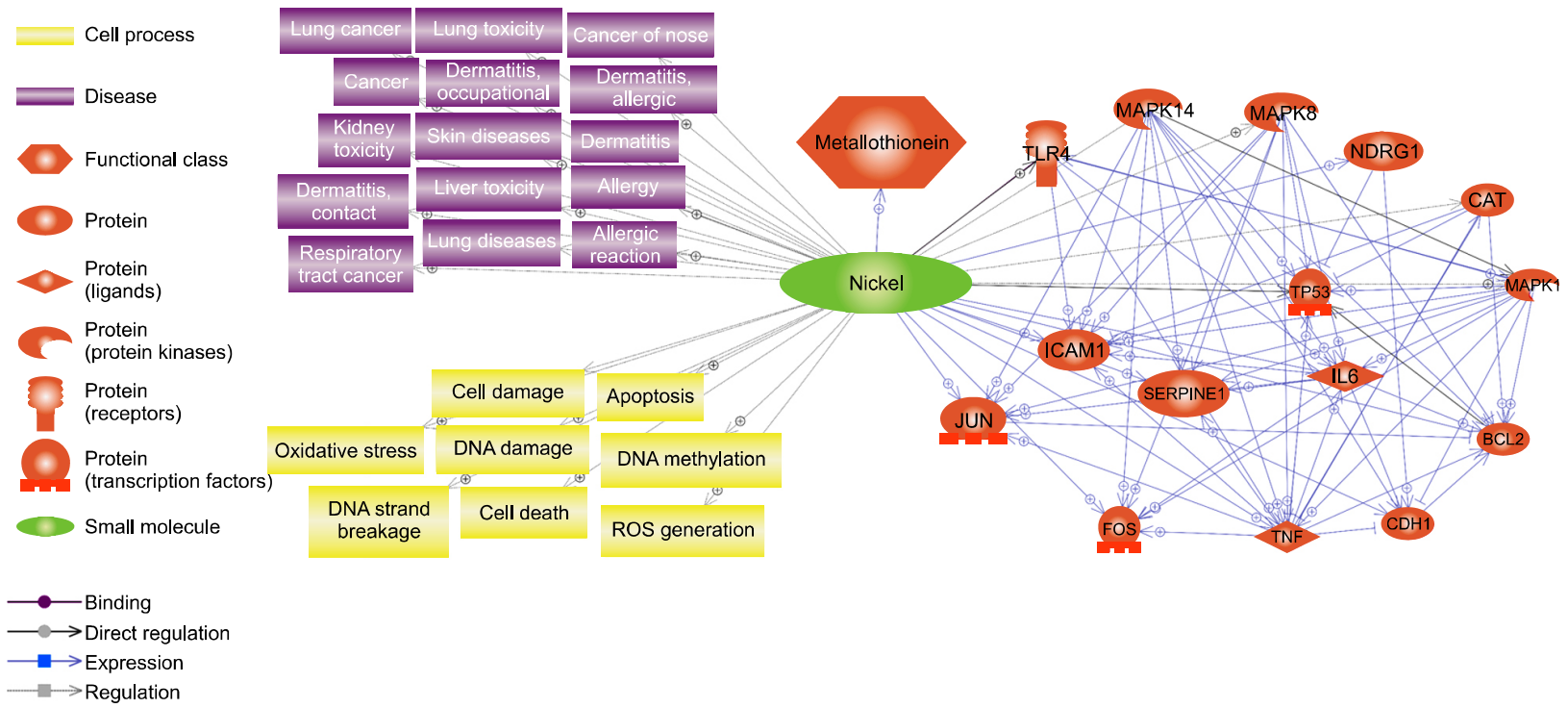

Figure 4. Pathway analysis of nickel toxicity. The analyzed data showed the potentials of genomic interaction, cellular processes, and diseases induced by exposure of nickel. 15 proteins, 8 cellular processes, 15 diseases, 1 small molecule and 1 functional class appeared in figure. ROS, reactive oxygen species; TLR4, toll-like receptor 4; MAPK, mitogen-activated protein kinase; NDRG1, N-myc downstream regulated 1; CAT, catalase; TP53, tumor protein 53; ICAM1, Intercellular adhesion molecule 1; JUN, Jun proto-oncogene; SERPINE1, serine peptidase inhibitor, clade E, member 1; IL, interleukin; BCL2, B cell lymphoma 2 protein; FOS, Finkel-Biskis-jinkins murine osteosarcoma viral oncogene homolog; CDH1, cadherin 1.

\section{NICKEL (Ni)}

\section{Contamination source}

$\mathrm{Ni}$ is widely used for industrial purposes because of its physicochemical properties. It is utilized in alloys and various products including rechargeable batteries, coins, electroplates, pigments, and stainless steel. ${ }^{75.76} \mathrm{Ni}$ is a remarkable alloying agent for various metals including $\mathrm{Cr}$, lead, and $\mathrm{Cu}$; this is a major source of Ni exposure. ${ }^{77} \mathrm{Ni}$-plated pipe and faucets, Ni-containing stainless cookers, and products that are colored with Ni-based 
pigment are introduced into the soil and cause water pollution with Ni compound. Waste water and dust from mining and smelting processes of $\mathrm{Ni}$ production also contaminate the environment. Because of this, people are often exposed to $\mathrm{Ni}$ by inhalation, direct skin contact, and oral consumption. ${ }^{78}$

\section{Toxicity and carcinogenic mechanism}

Skin contact with Ni compounds through contaminated water, air, and children's toys result in dermatitis and allergy. ${ }^{79,80}$ Oral exposure to Ni also induces skin and oral epithelium damage. ${ }^{81-83}$ Industrial dust from $\mathrm{Ni}$ refineries contains water-insoluble $\mathrm{Ni}$ compounds including $\mathrm{Ni}_{3} \mathrm{~S}_{2}$ and $\mathrm{NiO}$, which are carcinogenic. Breathing in Ni-contaminated dust from Ni smelting, mining and tobacco smoking leads to significant damage to lungs and nasal cavities, resulting in occupational diseases such as lung cancer and nasal cancer in Ni refinery workers. ${ }^{13,78,84,85}$ Although the molecular carcinogenic mechanisms of Ni toxicity are not clear, several studies suggest that Ni exposure induces oxidative stress via a reduction in expression of antioxidant enzymes and DNA single- and double-strand breaking. ${ }^{86-88}$

In order to understand the carcinogenic mechanisms of $\mathrm{Ni}$, we analyzed molecular pathway using Pathway Studio (ver. 11.1.0.6) (Fig. 4). Figure 4 showed that Ni induce apoptosis, oxidative stress, DNA methylation, and DNA damage. We investigated
Ni-related genomic interactions among TP53, TNF, BCL2, etc. We also discovered that various toxicity in lung, nose, skin, kidney and liver were induced by Ni. Interaction of MT and Ni was also investigated. This result may aid to comprehensive understanding of Ni-related toxicity mechanisms.

\section{REDUCTION AND PREVENTION OF CANCER BY HEAVY METAL DETOXIFICATION}

Metal ions in living organisms can bind with other specific ligand molecules in a phenomenon called chelation. ${ }^{89}$ PCs are protein ligand molecules in plants which chelate metal ions when plants are exposed to heavy metals. ${ }^{15,16,90,91}$ Various studies investigated that PCs are synthesized from glutathione (GSH) by the enzyme PC synthetase, ${ }^{92,93}$ and end up forming GSH oligomers. Metallic ion-bound PCs are transported into vacuoles and successfully isolated from cellular proteins, ${ }^{92}$ and reduce heavy metal ion-induced damage (Fig. 5A).

A major factor in heavy metal-induced carcinogenesis is inhibition of DNA repair and DNA crosslinking with proteins via ROS generation. ${ }^{94}$ ROS, which include the hydroxyl radical (HO), the superoxide radical $\left(\mathrm{O}_{2}{ }^{-}\right)$, and hydrogen peroxide $\left(\mathrm{H}_{2} \mathrm{O}_{2}\right)$, leads to an imbalance in homeostasis between antioxidant and
A

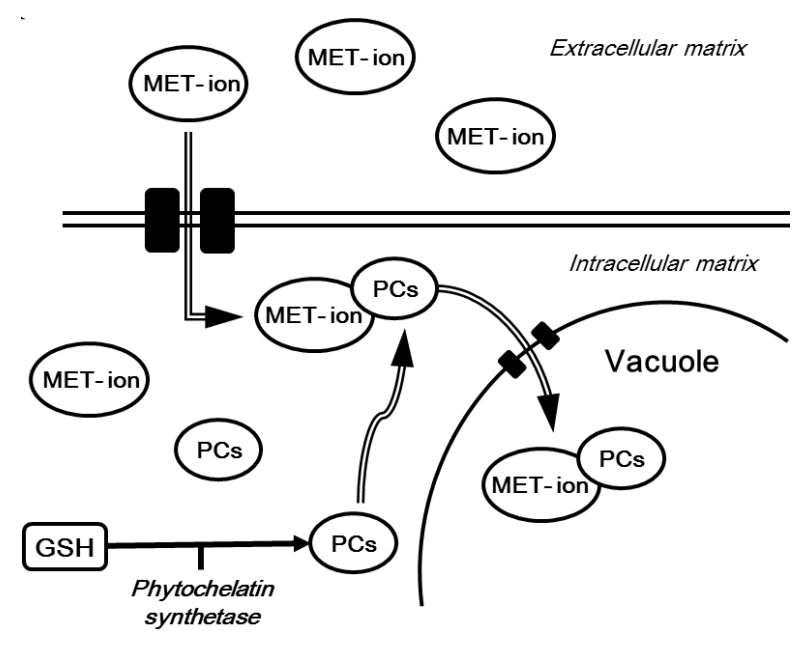

B

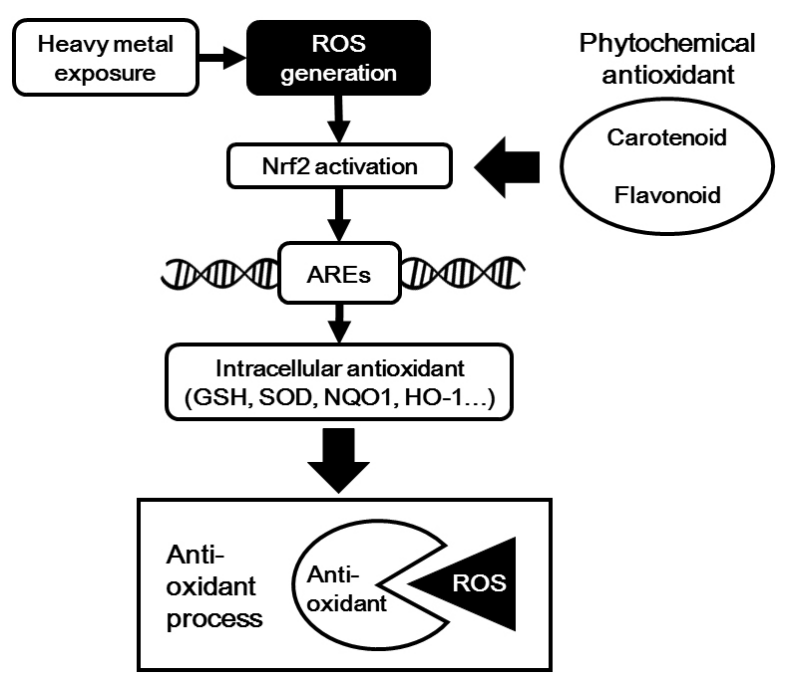

Figure 5. Mechanism of heavy metal detoxification via phytochelatin (PC) and antioxidants. (A) Schematic diagram of the PC pathway. Ionized forms of heavy metals are in bold circles marked as 'MET-ion'. PCs molecules are in bold circles marked as 'PCs'. A double-lined arrow indicates import direction. A bold arrow indicates the PCs synthesis process. Enzymes are written in an italicized bold font. (B) Schematic diagram of heavy metal-induced antioxidant processes. ROS generation by heavy metal exposure activates Nrf2, which is a transcription factor for antioxidant response elements (AREs). Phytochemicals contribute to antioxidative process via stimulation of the Nrf2 pathway. Various antioxidants are activated and remove ROS. GSH, glutathione; ROS, reactive oxygen species; SOD, superoxide dismutase; NQO1, NAD(P)H: quinone acceptor oxidoreductase 1; HO-1, heme oxygenase 1. 
pro-oxidant molecules and results in oxidative stress-related damage to cellular components such as proteins, DNA, and lipids. ${ }^{9,17,95}$ Intracellular antioxidant agents inhibit such process by removing ROS by being oxidized themselves and interacting with free radicals in ROS. ${ }^{17}$ There are various types and complex systems of intracellular antioxidants, including GSH, heme oxygenase 1 (HO-1), superoxide dismutase (SOD), $\mathrm{NAD}(\mathrm{P}) \mathrm{H}$ : quinone acceptor oxidoreductase 1 (NQO1), and catalases. ${ }^{17,18,95}$ Also, the nuclear factor (erythroid-derived 2)-like 2 (Nrf2) protein is well known as a regulator of antioxidant elements in reaction to oxidative stress. Nrf2 is activated by ROS and act as transcription factor that stimulates antioxidative genes through binding to antioxidant response element, which in the promoter region of antioxidative gene. ${ }^{96}$ Phytochemical substances, which include carotenoids and flavonoids, are also important antioxidants. They are found abundantly in vegetables and fruits; thus, regularly ingestion of those foods helps reduce damage from oxidative stress. ${ }^{18,97,98}$ We might conclude that above-mentioned antioxidant processes contribute to oxidative stress-induced cancer following heavy metal exposure (Fig. 5B).

\section{CONCLUSIONS}

Some heavy metals are significant toxicants and carcinogens. ${ }^{1}$ We discussed the major sources of exposure, toxicity, and carcinogenic mechanisms of four heavy metals in this review. Industrial development increases a risk of heavy metal exposure via production and consumption of commercial products containing heavy metal compounds. ${ }^{1,5-7}$ Direct or indirect exposure of heavy metals induces disruption of intracellular processes via complex pathway. In pathway analysis, we found some genes and processes that are common to the toxic effects of As, $\mathrm{Cd}, \mathrm{Cr}$, and Ni. These processes might be candidates for markers of heavy metal-induced carcinogenesis. In particular, oxidative stress-mediated pathways are common to toxicity of As, $\mathrm{Cd}, \mathrm{Cr}$, and Ni. We might suggest that antioxidative phytochemicals and chelating agents including PCs will be helpful for prevention of heavy metal-induced cancers. Furthermore, comprehensive understanding of these complex mechanisms by pathway analysis will be beneficial to research on the heavy metal-induced cancers and diseases.

\section{ACKNOWLEDGMENTS}

This study was supported by a 'The Ecoinnovation Project' (412-112-011) from the Korea Ministry of Environment.

\section{CONFLICTS OF INTEREST}

No potential conflicts of interest were disclosed.

\section{REFERENCES}

1. Tchounwou PB, Yedjou CG, Patlolla AK, Sutton DJ. Heavy metal toxicity and the environment. EXS 2012;101:133-64.

2. Fergusson JE. The heavy elements: chemistry, environmental impact and health effects. Oxford, Pergamon Press, 1990.

3. Stern BR. Essentiality and toxicity in copper health risk assessment: overview, update and regulatory considerations. J Toxicol Environ Health A 2010;73:114-27.

4. Hambidge KM, Krebs NF. Zinc deficiency: a special challenge. J Nutr 2007;137:1101-5.

5. Bánfalvi G. Heavy metals, trace elements and their cellular effects. In: Bánfalvi G, ed. Cellular Effects of Heavy Metals. New York, Springer, pp 3-28, 2011.

6. Finch LE, Hillyer MM, Leopold MC. Quantitative analysis of heavy metals in children's toys and jewelry: a multi-instrument multitechnique exercise in analytical chemistry and public health. J Chem Educ 2015;92:849-54.

7. Worsztynowicz A, Mill W. Potential ecological risk due to acidification of heavy industrialized areas: the upper silesia case. In: Erisman JW, Heij GJ, eds. Acid Rain Research: Do We Have Enough Answers? Burlington, Elsevier, pp 353-66. 1995.

8. IARC monographs on the evaluation of carcinogenic risk to human. Volume 100C. Lyon, International Agency for Research on Cancer, 2012.

9. Ercal N, Gurer-Orhan H, Aykin-Burns N. Toxic metals and oxidative stress part I: mechanisms involved in metal-induced oxidative damage. Curr Top Med Chem 2001;1:529-39.

10. Harvey PJ, Handley HK, Taylor MP. Identification of the sources of metal (lead) contamination in drinking waters in north-eastern Tasmania using lead isotopic compositions. Environ Sci Pollut Res Int 2015:22:12276-88.

11. Gul N, Shah MT, Khan S, Khattak NU, Muhammad S. Arsenic and heavy metals contamination, risk assessment and their source in drinking water of the Mardan District, Khyber Pakhtunkhwa, Pakistan. J Water Health 2015;13:1073-84.

12. Grimsrud TK, Andersen A. Unrecognized risks of nickel-related respiratory cancer among Canadian electrolysis workers. Scand J Work Environ Health 2012;38:503-15.

13. Grimsrud TK, Berge SR, Martinsen JI, Andersen A. Lung cancer incidence among Norwegian nickel-refinery workers 1953-2000. J Environ Monit 2003:5:190-7.

14. Khatri P, Sirota M, Butte AJ. Ten years of pathway analysis: current approaches and outstanding challenges. PLoS Comput Biol 2012;8:e1002375.

15. Cobbett CS. Phytochelatin biosynthesis and function in heavymetal detoxification. Curr Opin Plant Biol 2000;3:211-6.

16. Cobbett CS. Phytochelatins and their roles in heavy metal detoxification. Plant Physiol 2000;123:825-32.

17. Sies H. Oxidative stress: oxidants and antioxidants. Exp Physiol 1997;82:291-5.

18. Lobo V, Patil A, Phatak A, Chandra N. Free radicals, antioxidants and functional foods: Impact on human health. Pharmacogn Rev 2010;4:118-26. 
19. Grund SC, Hanusch K, Wolf HU. Arsenic and arsenic compounds, Ullmann's encyclopedia of industrial chemistry. Weinheim, Wiley-VCH, 2005.

20. Hopenhayn-Rich C, Biggs ML, Smith AH, Kalman DA, Moore LE. Methylation study of a population environmentally exposed to arsenic in drinking water. Environ Health Perspect 1996;104:6208.

21. Chung JY, Yu SD, Hong YS. Environmental source of arsenic exposure. J Prev Med Public Health 2014:47:253-7.

22. Jennewein M, Lewis MA, Zhao D, Tsyganov E, Slavine N, He J, et al. Vascular imaging of solid tumors in rats with a radioactive arsenic-labeled antibody that binds exposed phosphatidylserine. Clin Cancer Res 2008;14:1377-85.

23. Cross JD, Dale IM, Leslie ACD, Smith H. Industrial exposure to arsenic. J Radioanal Chem 1979:48:197-208.

24. Raj A, Singh N. Phytoremediation of arsenic contaminated soil by arsenic accumulators: a three year study. Bull Environ Contam Toxicol 2015;94:308-13.

25. Azizur Rahman M, Hasegawa H, Mahfuzur Rahman M, Mazid Miah MA, Tasmin A. Arsenic accumulation in rice (Oryza sativa L.): human exposure through food chain. Ecotoxicol Environ Saf 2008:69:317-24

26. Shi H, Shi X, Liu KJ. Oxidative mechanism of arsenic toxicity and carcinogenesis. Mol Cell Biochem 2004;255:67-78.

27. Flora SJ. Arsenic-induced oxidative stress and its reversibility. Free Radic Biol Med 2011:51:257-81.

28. Pai MH, Chien YW, Tsai YH, Hu YM, Yeh SL. Glutamine reduces the expression of leukocyte integrins leukocyte function-associated antigen- 1 and macrophage antigen- 1 in mice exposed to arsenic. Nutr Res 2008:28:544-9.

29. Saleha Banu B, Danadevi K, Jamil K, Ahuja YR, Visweswara Rao K, Ishaq $M$. In vivo genotoxic effect of arsenic trioxide in mice using comet assay. Toxicology 2001;162:171-7.

30. Gonsebatt ME, Vega L, Herrera LA, Montero R, Rojas E, Cebrián $\mathrm{ME}$, et al. Inorganic arsenic effects on human lymphocyte stimulation and proliferation. Mutat Res 1992;283:91-5.

31. Hartwig A, Schwerdtle T. Interactions by carcinogenic metal compounds with DNA repair processes: toxicological implications. Toxicol Lett 2002;127:47-54.

32. Mass MJ, Tennant A, Roop BC, Cullen WR, Styblo M, Thomas DJ, et al. Methylated trivalent arsenic species are genotoxic. Chem Res Toxicol 2001; 14:355-61.

33. Bau DT, Wang TS, Chung CH, Wang AS, Wang AS, Jan KY. Oxidative DNA adducts and DNA-protein cross-links are the major DNA lesions induced by arsenite. Environ Health Perspect 2002;110 Suppl 5:753-6.

34. Goering PL, Aposhian HV, Mass MJ, Cebrián M, Beck BD, Waalkes MP. The enigma of arsenic carcinogenesis: role of metabolism. Toxicol Sci 1999:49:5-14.

35. Cohen SM, Ohnishi T, Arnold LL, Le XC. Arsenic-induced bladder cancer in an animal model. Toxicol Appl Pharmacol 2007;222: 258-63.

36. Li W, Wanibuchi H, Salim EI, Yamamoto S, Yoshida K, Endo G, et al. Promotion of NCI-Black-Reiter male rat bladder carcinogenesis by dimethylarsinic acid an organic arsenic compound. Cancer Lett 1998;134:29-36.

37. Patlolla AK, Todorov TI, Tchounwou PB, van der Voet G, Centeno JA. Arsenic-induced biochemical and genotoxic effects and distribution in tissues of Sprague-Dawley rats. Microchem J 2012; 105:101-7.

38. Wilson K, Yang H, Seo CW, Marshall WE. Select metal adsorption by activated carbon made from peanut shells. Bioresour Technol 2006; $97: 2266-70$.

39. Morrow H. Cadmium electroplating. Metal Finish 1999;97:210-4.

40. Sathyanarayana S, Venugopalan S, Gopikanth ML. Impedance parameters and the state-of charge. I. Nickel-cadmium battery. J Appl Electrochem 1979;9:125-39.

41. Kawasaki T, Kono K, Dote T, Usuda K, Shimizu H, Dote E. Markers of cadmium exposure in workers in a cadmium pigment factory after changes in the exposure conditions. Toxicol Ind Health 2004;20:51-6.

42. Harries ML, Lam S, MacAulay C, Qu J, Palcic B. Diagnostic imaging of the larynx: autofluorescence of laryngeal tumours using the helium-cadmium laser. J Laryngol Otol 1995;109:108-10.

43. Lorenz SE, Hamon RE, McGrath SP, Holm PE, Christensen TH. Applications of fertilizer cations affect cadmium and zinc concentrations in soil solutions and uptake by plants. Eur J Soil Sci 1994:45:159-65.

44. Nogawa K, Kobayashi E, Okubo Y, Suwazono Y. Environmental cadmium exposure, adverse effects and preventive measures in Japan. Biometals 2004;17:581-7.

45. Poldoski JE. Cadmium bioaccumulation assays. Their relationship to various ionic equilibria in lake superior water. Environ Sci Technol 1980;14:735.

46. Frazier JM. Bioaccumulation of cadmium in marine organisms. Environ Health Perspect 1979;28:75-9.

47. Shaikh ZA, Vu TT, Zaman K. Oxidative stress as a mechanism of chronic cadmium-induced hepatotoxicity and renal toxicity and protection by antioxidants. Toxicol Appl Pharmacol 1999;154: 256-63.

48. Müller L. Consequences of cadmium toxicity in rat hepatocytes: mitochondrial dysfunction and lipid peroxidation. Toxicology 1986;40:285-95.

49. Casalino E, Calzaretti G, Sblano C, Landriscina C. Molecular inhibitory mechanisms of antioxidant enzymes in rat liver and kidney by cadmium. Toxicology 2002;179:37-50.

50. Andrews GK. Regulation of metallothionein gene expression by oxidative stress and metal ions. Biochem Pharmacol 2000;59:95104.

51. Nordberg GF, Goyer R, Nordberg M. Comparative toxicity of cadmium-metallothionein and cadmium chloride on mouse kidney. Arch Pathol 1975;99:192-7.

52. Dudley RE, Gammal LM, Klaassen CD. Cadmium-induced hepatic and renal injury in chronically exposed rats: likely role of hepatic cadmium-metallothionein in nephrotoxicity. Toxicol Appl Pharmacol 1985:77:414-26.

53. Baba H, Tsuneyama K, Yazaki M, Nagata K, Minamisaka T, Tsuda $\mathrm{T}$, et al. The liver in itai-itai disease (chronic cadmium poisoning): pathological features and metallothionein expression. Mod Pathol 2013;26:1228-34.

54. Takebayashi S, Jimi S, Segawa M, Kiyoshi Y. Cadmium induces osteomalacia mediated by proximal tubular atrophy and disturbances of phosphate reabsorption. A study of 11 autopsies. Pathol Res Pract 2000;196:653-63.

55. James KA, Meliker JR. Environmental cadmium exposure and osteoporosis: a review. Int J Public Health 2013;58:737-45.

56. Yang O, Kim HL, Weon JI, Seo YR. Endocrine-disrupting chemicals: review of toxicological mechanisms using molecular pathway analysis. J Cancer Prev 2015;20:12-24.

57. Jahan S, Khan M, Ahmed S, Ullah H. Comparative analysis of antioxidants against cadmium induced reproductive toxicity in adult male rats. Syst Biol Reprod Med 2014;60:28-34. 
58. Itoh H, Iwasaki M, Sawada N, Takachi R, Kasuga Y, Yokoyama S, et al. Dietary cadmium intake and breast cancer risk in Japanese women: a case-control study. Int J Hyg Environ Health 2014:217: 70-7.

59. Henson MC, Chedrese PJ. Endocrine disruption by cadmium, a common environmental toxicant with paradoxical effects on reproduction. Exp Biol Med (Maywood) 2004:229:383-92.

60. Barceloux DG. Chromium. J Toxicol Clin Toxicol 1999;37:173-94.

61. Dayan AD, Paine AJ. Mechanisms of chromium toxicity, carcinogenicity and allergenicity: review of the literature from 1985 to 2000. Hum Exp Toxicol 2001;20:439-51.

62. Eastmond DA, Macgregor JT, Slesinski RS. Trivalent chromium: assessing the genotoxic risk of an essential trace element and widely used human and animal nutritional supplement. Crit Rev Toxicol 2008:38:173-90.

63. Katz SA, Salem H. The toxicology of chromium with respect to its chemical speciation: a review. J Appl Toxicol 1993;13:217-24.

64. Kotaś J, Stasicka Z. Chromium occurrence in the environment and methods of its speciation. Environ Pollut 2000;107:263-83.

65. Langård S, Vigander T. Occurrence of lung cancer in workers producing chromium pigments. Br J Ind Med 1983;40:71-4.

66. Luippold RS, Mundt KA, Austin RP, Liebig E, Panko J, Crump C, et al. Lung cancer mortality among chromate production workers. Occup Environ Med 2003:60:451-7.

67. Garg UK, Kaur MP, Garg VK, Sud D. Removal of hexavalent chromium from aqueous solution by agricultural waste biomass. J Hazard Mater 2007;140:60-8.

68. Costa M. Potential hazards of hexavalent chromate in our drinking water. Toxicol Appl Pharmacol 2003;188:1-5.

69. Park RM, Bena JF, Stayner LT, Smith RJ, Gibb HJ, Lees PS. Hexavalent chromium and lung cancer in the chromate industry: a quantitative risk assessment. Risk Anal 2004:24:1099-108.

70. Shi XL, Dalal NS. The role of superoxide radical in chromium (VI)-generated hydroxyl radical: the $\mathrm{Cr}(\mathrm{VI})$ Haber-Weiss cycle. Arch Biochem Biophys 1992;292:323-7.

71. Hamilton JW, Wetterhahn KE. Chromium (VI)-induced DNA damage in chick embryo liver and blood cells in vivo. Carcinogenesis 1986;7:2085-8.

72. Dartsch PC, Hildenbrand S, Kimmel R, Schmahl FW. Investigations on the nephrotoxicity and hepatotoxicity of trivalent and hexavalent chromium compounds. Int Arch Occup Environ Health 1998;71 Suppl:S40-5.

73. Aiyar J, Berkovits HJ, Floyd RA, Wetterhahn KE. Reaction of chromium(VI) with glutathione or with hydrogen peroxide: identification of reactive intermediates and their role in chromium(VI)induced DNA damage. Environ Health Perspect 1991;92:53-62.

74. Gammelgaard B, Fullerton A, Avnstorp C, Menné T. Permeation of chromium salts through human skin in vitro. Contact Dermatitis 1992;27:302-10.

75. Kuck PH. Mineral yearbook 2006: nickel. http://minerals.usgs. gov/minerals/pubs/commodity/nickel/myb1-2006-nicke.pdf. United States Geological Survey. Accessed July 8, 2008.

76. International Agency for Research on Cancer. IARC monographs on the evaluation of carcinogenic risks to humans. vol. 49. Chromium, nickel and welding. Lyon, IARC Scientific Publications, pp 257-445, 1990.

77. Joseph RD. Uses of nickel. In: Davis JR, ed. ASM Specialty Handbook: Nickel, Cobalt, and Their Alloys. Materials Park, OH, ASM International, pp 7-13, 2000.

78. Kasprzak KS, Sunderman FW Jr, Salnikow K. Nickel carcino- genesis. Mutat Res 2003:533:67-97.

79. Nielsen NH, Menné T, Kristiansen J, Christensen JM, Borg L, Poulsen LK. Effects of repeated skin exposure to low nickel concentrations: a model for allergic contact dermatitis to nickel on the hands. Br J Dermatol 1999;141:676-82.

80. Jacob SE, Goldenberg A, Pelletier JL, Fonacier LS, Usatine R, Silverberg N. Nickel allergy and our children's health: a review of indexed cases and a view of future prevention. Pediatr Dermatol 2015:32:779-85

81. Spiechowicz E, Glantz PO, Axéll T, Chmielewski W. Oral exposure to a nickel-containing dental alloy of persons with hypersensitive skin reactions to nickel. Contact Dermatitis 1984;10:206-11.

82. Gawkrodger DJ, Cook SW, Fell GS, Hunter JA. Nickel dermatitis: the reaction to oral nickel challenge. Br J Dermatol 1986;115:33-8.

83. Trombetta D, Mondello MR, Cimino F, Cristani M, Pergolizzi S, Saija A. Toxic effect of nickel in an in vitro model of human oral epithelium. Toxicol Lett 2005;159:219-25.

84. Doll R, Morgan LG, Speizer FE. Cancers of the lung and nasal sinuses in nickel workers. Br J Cancer 1970;24:623-32.

85. Küpper M, Weinbruch S, Skaug V, Skogstad A, Thornér EE, Benker $\mathrm{N}$, et al. Electron microscopy of particles deposited in the lungs of nickel refinery workers. Anal Bioanal Chem 2015;407:6435-45.

86. Lynn S, Yew FH, Chen KS, Jan KY. Reactive oxygen species are involved in nickel inhibition of DNA repair. Environ Mol Mutagen 1997:29:208-16

87. Chakrabarti SK, Bai C, Subramanian KS. DNA-protein crosslinks induced by nickel compounds in isolated rat lymphocytes: role of reactive oxygen species and specific amino acids. Toxicol Appl Pharmacol 2001;170:153-65.

88. Kim HL, Seo YR. Molecular and genomic approach for understanding the gene-environment interaction between Nrf2 deficiency and carcinogenic nickel-induced DNA damage. Oncol Rep 2012;28:1959-67.

89. McNaught $\mathrm{AD}$, Wilkinson A. Compendium of chemical terminology. Oxford, Blackwell Science, 1997.

90. Cobbett C, Goldsbrough P. Phytochelatins and metallothioneins: roles in heavy metal detoxification and homeostasis. Annu Rev Plant Biol 2002;53:159-82.

91. Kinnersley AM. The role of phytochelates in plant growth and productivity. Plant Growth Regul 1993:12:207-18.

92. Rauser WE. Phytochelatins and related peptides. Structure, biosynthesis, and function. Plant Physiol 1995;109:1141-9.

93. Rauser WE. Structure and function of metal chelators produced by plants: the case for organic acids, amino acids, phytin, and metallothioneins. Cell Biochem Biophys 1999;31:19-48.

94. Snow ET. Metal carcinogenesis: mechanistic implications. Pharmacol Ther 1992;53:31-65.

95. Vertuani S, Angusti A, Manfredini S. The antioxidants and proantioxidants network: an overview. Curr Pharm Des 2004;10: 1677-94.

96. Huang HC, Nguyen T, Pickett CB. Regulation of the antioxidant response element by protein kinase C-mediated phosphorylation of NF-E2-related factor 2. Proc Natl Acad Sci U S A 2000;97: 12475-80.

97. Wolfe K, Wu X, Liu RH. Antioxidant activity of apple peels. J Agric Food Chem 2003:51:609-14.

98. Wang S, Meckling KA, Marcone MF, Kakuda Y, Tsao R. Can phytochemical antioxidant rich foods act as anti-cancer agents? Food Res Int 2011:44:2545-54. 